\title{
MUSIC AND THE CONDITION OF BEING ALIVE: THE EXAMPLE OF SYLVIA TOWNSEND WARNER
}

\section{Gillian Beer}

Sylvia Townsend Warner was musician, composer and musicologist well into the thirties of her long life (18931978). She was then poet, novelist, writer of short-stories, translator of Proust, biographer of T.H. White, and a wonderful diarist and letter writer. How do the two phases connect and overlap? And how do they - indeed, do they? - connect with her commitments as a Communist during the 1930s and 40s and her experience first as the secret lover for seventeen years of her former music master and then as committed lover and life partner to Valentine Ackland, born Mary Ackland .

In 1977 the Aldeburgh Festival held a celebration of the life and work of Sylvia Townsend Warner (just a year before her death as it turned out). In her latter years Warner was a friend of Peter Pears and Benjamin Britten. She had given a collection of pictures by the East Anglian fisherman painter and needle-worker John Craske to the 
Snape-Maltings Foundation and had arranged an exhibition of his work there, with an introduction, in 1971. Yet the presence of a Wamer tribute within the Festival is intriguing. What was it about the example of her life and work that prompted such an event? And does that life and work have ways of speaking to us now? The programme of the Aldeburgh day gives a glimpse into the extraordinary range of her writing and the way her creativity fuelled others. It included settings of her poems by John Ireland, Alan Bush and Paul Nordoff. Peter Pears read from her early and late poetry collections as well as one of the many short stories she wrote for the New Yorker. The programme also included a Virelai and Rondeau for two voices by the fourteenth century composer Guillaume de Machaut, for Warner was a pioneer re-discoverer of early music with a special skill in transcribing ancient scores. The sound of Machaut haunts her novel The Corner that Held Them. I will return to her friendship with Pears and Britten and explore some of the items in the 1977 programme at the end of my argument.

Warner was always radical and unexpected, and yet was at home in a Dorset or a Norfolk village. She lived very thoroughly in the time of her own life, its politics, its tensions and contradictions, and its pleasures. Her singular life is deep embedded in what is held in common. So despite social changes her writing rarely seems dated. It is extraordinarily free, light-winged, and often funny, as clear as a bell and unforeseeable as the future. It is also preoccupied with suffering and privation. Each of her novels, from Lolly Willowes, through Mr.Fortune's Maggot, Summer Will Show, After the Death of Don Juan to The Corner that Held Them, is a fresh start in a new direction. Her short stories, of which more than a hundred and fifty were published in the New Yorker, are alert to the music - and the cacophony - of human voices, and they listen intently to human silences. The hesitations of speech, the pauses between written paragraphs, the summary force of cries, all go into the scoring of her dialogues and her commentary. Music is in the grain of her prose, her plotting, and her life. 
Sylvia was not appreciated at her infants' school, it seems. She mimicked the teachers and made the other children laugh. Her parents were asked to withdraw her. But her report did contain one positive comment: 'Sylvia always sings in tune.' (Harman 1989, p.8) That could stand as an epigraph to her life and works. Across their extraordinary variety of tonality, her pitch was perfect and unwavering. Rippling through her work, and sounding through her life, is music: music heard, music played, music composed, music re-imagined and revived, music cross-hatched with dissonance too. Her commitments were enduring, but her array of talents, and her capacity for imagining other lives and ways of being, made for complication. Always rueful in her humour, she occasionally draws direct and with verve on her own life history, as in the short story 'Out of My Happy Past' which opens:

When I was young there were two things that I lived for. One was music and the other was advice. In the matter of music I was fairly eclectic; I liked listening to it, performing it, transcribing it, and composing it. In the matter of advice my tastes were purer; I only liked giving it and, to interest me, it had to be uncontaminatedly my own. Warner 1943, p.123

An only child, she was educated at home where her father was history master at Harrow. From the age of sixteen her music master was the older, distinguished - and married musician Percy Buck (who she always called Teague). Buck appreciated her talents as a composer and nurtured her unusual musical skills as performer and composer and also as theorist and editor. By the time she was twenty they were secretly lovers and remained so, somewhat off and on, into her thirties. There are said to have been plans for her to study with Schoenberg, thwarted by the outbreak of the first world war. At twenty three she joined the editorial board of the Carnegie-funded Tudor Church 
Music, founding text and source for the later early music revival. The other editors were all twenty years older than she but Richard Terry, the leading expert on early sixteenth century polyphony and senior editor of the project, wrote of her as:
A most brilliant musician and a pupil of Buck. I only began teaching her the old notation last year, and now she is scoring the stiffest things of the Fayrfax period that 1 can find. She is more than clever, in fact she is nothing short of a genius.
Bodleian. Ms. Mus.C 88:117 quoted in Searle 2011, p.74

The Tudor Church Music project lasted from 1917 until 1928 and produced ten major volumes, including those for Tallis, White, Taverner and Byrd. Already by the midtwenties, Warner was beginning to publish poetry and to weary of the constraints of scholarship, though its fires still burned in her: in a diary entry in September 1929 she recounts 'a slightly grubby day' of editing, then while looking for a musical example from William Byrd:

\begin{abstract}
At the bass entry on mortem Domini I was cast into such a rapture of knowing the man's mind that I was ready to count all the damnations of scholarship as nought for the sake of that one passage alone. O William, my dear, I said. And William chow [her dog] woke up, not knowing that the William I addressed had been bones for three hundred years.
\end{abstract}

$$
\text { Warner 1994, p.44 }
$$

That ecstatic moment presages the change that will fuel her future life work: the capacity to move freely across the divide between living and dead, across societies and time, and between imagined and breathing lives. 
The publication and great success of her first novel, Lolly Willowes, in 1926 charged her with new freedom and an impatience to leave scholarship behind. But those early years of toil, of silence in research libraries, and of an inner world of thought making music emerge anew from pneums and parts and mensurable conventions, survived in her. It is striking that Terry comments on the excellence of her 'contrapuntal knowledge'(Carnegie GD $281 / 41 / 224$, quoted Searle 2011, p.77). For that skill will enrich her writing throughout her career, with its intertwined narratives where the inner darker voices sometimes emerge, or are sometimes secreted.

In an interview in 1931 for 'Writers at Work', near the start of her writing career, Warner describes the long process of dormancy before beginning to write a book:

The idea floats up into my mind from somewhere. But it must take its shape before I think out any of the details, or even the characters. I used to compose music, and I believe I write like a composer still. I must get the shape first, before the actions or words.

Warner 2012 p.394

Again in 1975, near the end of her career, she declares herself still 'that odd thing, a musicologist' (Warner 2012, p.399) In conversation, she remarks that in her writing, particularly in her poetry:

I keep to a formal mode. I'm extremely fidgety about form, but that was because of music. I really learned all my ideas of form from studying music.

She then continues in a direction that might not have been foreseen:

Really I believe that the thing that forms the structure of any narrative and holds it 
together is the importance of the narrative, the interest one has in the narrative. That's why Defoe is such a master, because he's really interested in the story.

Warner 2012 pp. 404-5

How formal structure and human story can combine is the creative puzzle she persistently explores throughout the years of her work. Her poems are traditional in form, though what they say is often tonic, or even acrid. She explores also how to discover which stories are important, however humdrum or abstract or extreme they may be. Music is a chief resource for her in that exploration. She is alert to the similarities between vocal line and conversation as well as the closeness of human and animal sounds. Rhythm is cssential to meaning in her writing throughout her career. So, for example, on the $2^{\text {itd }}$ December 1951 she writes in her diary while working on her novel The Flint Anchor:

l spent most of the day casing round p. 160 \& what to do with Jemima. It hangs on me now a little, and re-reading it, $]$ am pained to find it too skittish in gait. I must re-rhythm some parts of it. Warner 1994, p.183

She relishes inconsistency but she values counterpoint. Rule, swerve and excess mark the measure of her stories. They are implacable and fun, a seemingly impossible combination.

In 1928 Warner destroyed most of the music she had composed between 1911 and 1915 and later, but she continued to collaborate with other composers. Perhaps the most successful setting of her poems was John Ireland's song cycle 'Songs Sacred and Profane' (19291931) which sets three of the poems of her first publication 'The Espalier' (1925). Each of the poems sizzles with irony and Ireland captures that wayward undersong in his setting: One of them, 'The Scapegoat' gets the peculiar measure of her creativity. In the town, 
the righteous congratulate themselves with heavy beat, on their deliverance from sin. Meanwhile, in the desert, the sacrificial goat, driven out to bear their sins and guarantee their absolution, goes his own way:

See the scapegoat, happy beast, From every personal sin released, And in the desert hidden apart, Dancing with a carcless heart.

'Lightly weight the sins of others.' See him skip! 'Am I my brother's Keeper? O never, no, no no! Lightly come and lightly go!'

In the town, from sin made frec, Righteous men hold jubilec.

In the desert all alone

The scapegoat dances on and on.' Warner 2008 p. 72

The carefree goat, like Lolly Willowes, exits from the cluttered world of guilt, and dances 'on and on'. Occasionally, even late in her life, Warner experiences the same freedom. On 14 1 th October 1958, listening to the radio, she heard the Amadeus Quartet:

In the evening the Amadeus played opus 123; and I danced to the last movement, I rose up \& danced, among the cats \& their saucers, and only when I was far too carried away to stop did I realise that I was behaving very oddly for my age -- and that perhaps it was the last time I should dance for joy.

Warner 1994, p.251

That mortified end to the sentence 'perhaps it was the last time I should dance for joy' strikes a sad note: after all she was only 65 in 1968. But her life had taken sombre turns as well as joyous ones, including the vicissitudes of 
Valentine Ackland's extended love affair with another woman, and later her Catholicism and ill health. She had seen the triumph of Franco and the coming of Hitler, and the cost of political idealism. Sylvia was aghast by the personal betrayal of Valentine's affair but even more by the distance that religious belief placed between them. Although herself imbued with church music, and loving old churches and the harmonies of church bells - which she repeatedly describes in her diaries with technical precision and the pleasures of the ear - Warner was yet implacably opposed to religious conformity and to the shrivelled consequences of Christian practice.

In the 1930s what bound Ackland and Warner together was not only personal but political. $\ln 1935$, aghast by the rise of Fascism and by the poverty and social inequities they saw in the Dorset village where they settled, they both became members of the Communist party. Warner wrote an excoriating attack on the BMA's 1933 nutrition advice for families living on the dole, a pamphlet which included recipes for supper for five pcople: for example: 'Sausages in Batter: half a pound of sausages. Skin the sausages and roll them in twclve portions.' (between five people). She titled her review: 'Recommendations to Starvation' and it ended:

Science, medical and domestic, all the jargon and apparatus of a cookery book, coloured plates and pious preface, spell but one word, Malnutrition. Or in plainer English, Not Enough to Eat.

Warner 2011, p.18

Her musical life at this period is bound up with other leftwing composers, particularly John Ireland and Alan Bush, both of whom set her poems. Indeed, Bush's song-cycle 'The Freight of Harvest', which set some of her poems, was performed later on at the 1977 Aldeburgh celebration. (It must be whispered that she had mixed feelings about his work, in her diary calling one earlier piece 'Vaughan Williams with cocoa'.) She believed 
towards the end of her life that her leftwing views had impeded the success of her great friend and collaborator the American composer Paul Nordoff's opera on the last days of Shelley, for which she had written the libretto. Columbia [University] commissioned it but then:

reneged, in a fit of Mc Carthy-mindedness because Paul \& I were both badged with unsound political views - Shelley too, for that matter - and unsuitable for support. ... One never knows who one offends. A setting of my "Country Thoughts from a Town' by Alan Bush distressed his highmindedness by mentioning God, and he had to ask me to tone God down into nature, or something inoffensive like that. So I did. People with tender consciences have enough to suffer without their scruples being trampled on. There should be scruple-pads as with corns.

Warner 2001 a, p. 319

That affectionate impatient tone tosses aside portentousness, and tosses in the absurdity of thinking nature inoffensive. She came to dislike anything politically programmatic in music. But in the 1930 s her feelings were more single-minded.

Both Warner and Ackland were kept under surveillance for twenty years from 1935 by MI5 and their files also make clear that the police and MI5 found Warner's social status and political views puzzlingly at odds. The local policeman declared himself

somewhat nervous of making enquiries about these people [her visitors from London], and said that owing to Miss Warner's social standing in the county it was very difficult to obtain any information.

Bond and Jacobs 2008, p.49 
Warner, as Bond and Jacobs point out in their excellent article on these matters, was 'diligent in 'pursuit of accommodation and guarantors for endangered European anti-fascist writers seeking refuge in the UK.' (p.54) She and Valentine travelled with the Red Cross to Spain at the time of the civil war and again to a writers' conference there during the conflict. She whole-heartedly affirmed the cause of the International Brigade, and, much more, the Spanish people and wrote about them for the British press.

Indeed, that Spanish experience is the foundation of one of her most extraordinary novels, After the Death of Don Juan (1938), a kind of allegory of the Spanish Civil War. The book opens as an absurdist extension of Don Giovami, both Mozart's opera and Moliere's play. Dôna Ana and Don Ottavio set off with their servants across mountains and valleys to bring the news of Don Giovanni's death to his old father. This unnecessary expedition covers up Ana's obsession with the profligate. Ottavio, an ineffectual companion, finds comfort by playing persistently upon his penny whistle or flageolet (a sly innuendo). The first part of the novel satirises all the effusive (delusive) pastoralism of the aristocracy expecting flowers and shepherdesses, perhaps a dig at Don Giovanni, over against the bleak and deadly poverty of the villagers on the estate when at last they reach it. But as the book progresses, more and more village people are explored in all their diversity, and the intricacies and the force of revolutionary politics are realised in this place remote from the handles of national power. Describing the crowd she writes:

To the angry hum of discussion was added the sharper narrative accents of those telling their story of Don Juan at the window and Dõna Ana on the steps, and the third counterpoint of questions and ejaculations from the new arrivals.

Warner 1989 p.231 
Moreover, Don Juan is not dead; he re-appears, intent on wresting the estate from his benign, ineffectual father and driving out the poor for profit. Eroticism and capitalism here prove to be two expressions of the same will to power. The book ends in calamity for the villagers, slaughtered by soldiers summoned by Don Juan. It ends also with the dignity of the villagers' resistance and its destructive glory, dangerously alluring. The description of the peasant leader Diego evokes musical experience to compel insight into the gratification of the revolutionary moment. The revolutionaries are cooped up in a room waiting for the soldiers' attack:

To Diego the act of whistling was an accompaniment to the pause in fighting, like an interminable holding-note in music between one strophe and another. From the moment when he had jumped down from the wall he had entered a new life, a life of unassailable happiness, a life in which every detail, every horror, every bungle, stood out brilliant and unequivocal, as in a landscape bathed in sunlight. The mistrust, the unsatisfied egoism, which had tomented him all his life long had shrivelled and vanished. He felt secure in the love of his fellows, brotherly affection laced them all, living and dead, into a harmony where there was no compulsion, no bending of the individual from its true intonation. Secure in love, secure in hate. His hate was released and ran loose, beautiful in the sunlight, rejoicing like some wild animal loosed from a cage in which it would have grown unmuscular and shabby.

p.299

Harmony, intonation, sunlight, hatred, absolute being in extremis, meld in this passionate and subtle psychological 
description. Alongside Diego and his englamoured freedom, Ramon, the thoughtful, is dying.

Afier the Death of Don Juan is remarkable for its evocation, without pastiche, of voices distant from its readers in time and culture and class. The arguments among the peasants have a spaciousness that suggests formality from another age, but with sharp swerves into pithy rejoinder. And Warner is able to handle large casts of characters within the same conversation, again with skills learnt from musical composition and polyphony. In this novel, her writing is flexible enough to encompass a multitude of voices, each with its own melody and pursuing its own path. That capacity is also what allows her a final detachment that is never fooled by heroics or neediness, but is always listening.

At the start of her writing career Lolly Willowes (1926) revelled in freedom achieved against the odds. Laura, called Lolly by her controlling family, escapes in middle age to the countryside where she discovers that the village she has settled in is a coven of witches. She joins them in wild night time dances and she willingly, and without apparent ill consequences, gives herself to the devil. This, understandably, was the most successful commercially of her books, since here radical actions produce no harm. The playful, if menacing, tone of rejoinder in that book is tempered in her later writing by a growing realisation that it is impossible to control all the consequences of actions. That recognition requires that we come to know how little we know of others' minds. It also demands that we acknowledge, and do not disown, our own absurdities.

Her short stories persistently illuminate the baffled contact between people who do not understand each other, partly because they do not listen to each other, or because they are unable to speak their thoughts. At the same time many of the stories acknowledge the necessity and the frailty of secrets. One, profound and heartrending, is 'Idenborough' (1988a) where a sudden rupture of feeling occurs between a woman and her loving second husband; he is grief-stricken and dismayed. She is intensely remembering a much earlier secret love-affair 
during her first marriage. The painful rumination of that story is completely different from the sharp comedy in some others, for example, 'On Living for Others' (1988a). Warner has an adept satiric ear for the social nuances and confusions that gather around differing tastes in music: and how readily music, property and ownership can get confused. In 'On Living For Others' a composer turns back at the train junction with relief instead of going to hear his own orchestration of a seventeenth century masque followed by a committee meeting of the Ferrabosco Society (a glance back at all her own committee work for Tudor Church Music): he thinks:
A meeting of the Advisory Committee would follow, and afterwards he was to dine and slecp at Adela Turpin's flat, where he would find Humphrey Dudgeon, whose opera on Hamnibal was in rehearsal for the Aldeborough Festival. If only he had not made that silly joke.... One should never make jokes on the phone; the acoustics aren't right for it. To his inquiry how a sufficiency of elcphants could be got on to that small stage Adela had replied, 'But it's opera da camera, darling!' Thoughts of this, and of the Advisory Committee, where Hilda Carpentras would repeat that the 'cello is no real substitute for the viola da gamba and everyone would snub old Jones, assailed him.
Warner 1988a pp. 189

He goes home instead. Where he encounters new complexities, his cleaner asleep with her lover in his bed. He feels it would be improper to rouse them so he must while away the time elsewhere until they leave. Later, his commissioned mass is rejected as 'not sincere' by the rich Mrs. Pilkington to the secret relief of this somewhat condescending composer. She is affronted at the start when in the church he offers to play through his ideas to her on the harmonium. 
'But why can't you play it on the organ?

Can't you play the organ?'

'I prefer the harmonium for a capella.'

p.194-195

His grand explanation is as pretentious as the group he has avoided.

The harmonium, in Warner's work, is freighted with modest meanings. It can be a practice instrument substituting in church rehearsal for the organ but it was also an instrument within the pocket of working class musicians. (It was my own first instrument as a small girl. I still remember the wheeze of the bellows which you pumped with your feet.) In her diary Warner describes the pleasure of walking between cottages and hearing harmoniums playing in each of them. And of course, Mr. Fortune, that innocent soul, loves his harmonium and takes it with him to his desert island.

In another discomfiting talc, 'Music at Long Verney' the old couple from the old family let the house to the businessman from London. He has discriminating tastes. 'Music and finance were his interests. He had an exquisite ear for both.' (Warner $200 \mathrm{lb}, \mathrm{p} .10$ ) In both 'Music at Long Verney' and 'On Living For Others' music is muddled up with social unease and claimed superiority so that the reader reads with zest and embarrassment, vacillating among the characters. There is a caustic cdge to the writing that makes it hard to place yourself because there is no safe outside spot. We have to face our own snobbery as well as relish the discomfiture of the snobs in the stories. Snobbery is such a shape-shifter, tamishing pure delight. STW's satire pinpoints impure pleasures but lets us enjoy them too.

It is nearly impossible to encompass the range of these stories, from the tender and subtle comedy of 'A Love Match' (1988a) about the incestuous domestic happiness of a brother and sister to the comic éclat and dour ending of 'The Foregone Conclusion'. That story opens: 
She planted a high Spanish comb in her pubic hair and resumed her horn-rimmed spectacles.

'There! That's as much as I shall dress.'

It ends:

He drew a deep breath. Presently he got out at the right station. Wamer 1988a pp.36; 39

This late-written story of two musical lovers, an older married man and a young woman, who had first met at a concert, and who are now, it turns out, coming to the end of their affair, seems to draw on her own young experience. Only after you finish the story does it become clear that throughout the course of the account, you have been reading the situation entirely through the man's eyes. Then at last the clichéd title 'The Foregone Conclusion' begins to vibrate: 'foregone' is predetermined, with the accent on the first syllable, but also, with the accent on the second syllable, 'foregone, what has been lost or sacrificed.

Warner published her more than 150 stories from 1932 to 1977 in the New Yorker. That source of income was essential to their domestic economy, as well as a constant outlet to her creativity, and it is striking that despite her suspicions of McCarthy-ite tendencies around the blocking of Nordoff's opera, she seems never to have had any such problem with her editors at the New Yorker. Indeed, the novelist and editor William Maxwell was one of her most appreciative friends and readers for many years. So there are inconsistencies in Warner's position, and that she would not have denied: in her late interview she cites Whitman in her defence: 'I remember a passage in Walt Whitman where someone or other is accusing him of being inconsistent and he says, 'Am I inconsistent? Well, I am inconsistent. Within me I contain millions!' (Warner 2012, p.405) That get-out clause does not do justice to the persistence with which she investigated inconsistency or to her adamant refusal to settle for easy consonance. It's striking how various are the titles of 
books by other people about her life and work: This Narrow Place, The Element of Lavishness, With the Hunted, for example. Something cloistered, something exuberant, something committed to the outsider: all these are aspects of her creativity, nor are they separate from each other but rather all active simultaneously, and contrapuntally.

All these elements come into play with her post-war and favourite - novel The Corner That Held Them (1948). The Corner That Held Them evokes years of the life of a medieval convent (from 1170, its ironic founding, and particularly from 1349 to 1382 , the novel's end). Birdsong and church bells and the shrieks of women form a surreal tapestry of sound to these lives. Music is here the medium of religious order, money its ground bass. The novel is Marxian in its emphasis on economic necessity and the humdrum processes of living. It is fascinated by materiality, the enchantment of texturc: apples, faces, grubs, and stone-work. It requires us to face the deepest miseries of poverty: Annis thinks:

No, the wretchedness of the poor lies below hunger and nakedness. It consists in their incessant incertitude and fear, the drudging succession of shift and scheme and subterfuge, the labouring in the quicksand where every step that takes hold of the firm ground is also a step into the danger of condemnation. Not cold and hunger but Law and Justice are the bitterest affliction of the poor.

Warner 1988b, p.257

But the description of life here encompasses also the experience of ecstatic music-making in the wonderful chapter 'Triste Loysir'. All Warner's early training in the techniques of musical transcription as well as her passionate immersion in the sonorities of fourteenth and fifteenth century music and Ars Nova come together here. Chaplain, visitor, and leper musician sing together, first 
Triste Loysir and then Machault's Kyrie from La Messe de Nostre Dame. The rapturous extension and the precision of the writing sweep the reader into the experience of singing completely new music together. First, tentatively, Henry Yellowlees

began loudly and steadily; but after half a dozen notes it seemed to him that he must have gone wrong, and he broke off. ... 'There was nothing wrong. Perhaps the interval unsettled you. You expected a fourth, no doubt. This is composed in the style of the Ars nova, it is disconcerting at times'.... This time he held on, though he felt himself astray, bewildered by the uncxpected progressions, concords so sweet that they seemed to melt the flesh off his bones.

pp.202-3

When they come to the Machatt:

The three voices sprang into the air.

If Triste Loysir had seemed a forctaste of paradise, the Kyrie was paradise itself. This was how the blessed might sing, in a duple measure that ran as nimbly on its four feet as a weasel running through a meadow, with each voice in turn enkindling the others, so that the music flowed on and was continually renewed. And as paradise is made for man, this music seemed made for man's singing; not for edification, or the working-out of an argument, or the display of skill, but only for ease and pleasure, as in paradise where the abolition of $\sin$ begets a pagan carelessness, where the certainty of Christ's countenance frees men's souls from the obligations of Christian behaviour, the creaking counterpoint of God's law and man's obedience.

pp. 203-204 
The voices of narrator and character and author concur in that flowing, intricate, and rhythmic sentence.

After the Celebration of her work at Aldeburgh in 1977 she wrote to William Maxwell that the 'finest part of the programme was when [Pears] and t'other tenor ... leaped back over six centuries \& sang two a cappella pieces by Machaut. You remember what I said about Machaut in The Corner That Held Them.' Now, you may go on u-tube and find a number of fine versions of the Kyrie, each in a very different performance style, but when she was writing it was hardly known: she very probably heard it in her head direct from the written score. Her scholarship fires the extraordinary inventiveness of her writing.

The chapter in the novel ends with death and destruction, the burning of the musical scores and killing, - and the writing keeps steady as it veers from one intensity to another. The nuns come forward in vivid description, all their names lovingly noted and repeated, their personalities tracked. They live lives marked each by grief, absurdity, ambition, illness, hope. They hate and adore their fellow postulants. Individualism is honoured and refuted. Systems survive; people don't. The nuns die in turn and are replaced in their offices, seamlessly or with difficulty. Buildings rise and fall, are restored, burn, are added to. And the convent continues through the rhythm of the year's seasons, through its periods of affluence and poverty. Individuals matter, and pass away. Change emerges without emphasis. Time enlarges. Events dissolve. The everyday, which seems eternal, does not last for ever. The rich intertwining of voices, speaking, shouting, whispering, intoning, resisting, and the sounds of birds and animals living their own lives, makes in this novel for an extraordinarily thick description of passing and of continuance: of being itself.

Such is Warner's prodigious productivity that it's not possible for me here even to allude to all the novels, poems, short stories, let alone all the brilliant accounts in her letters and diaries. Her diaries, much of them as yet 
unpublished, are full to the brim of music. Claire Harman, her pioneering biographer and editor, confronted with forty notebooks when editing the Diaries for publication as a single volume, made the decision to omit most of the discussions of particular compositions and concerts. I am most grateful to have been allowed while preparing this lecture to see further transcriptions made by Lymn Mutti.

In her youth the diaries are full of concerts, crisped with her incisive views on current composers and performers as well as earlier music. Frequently Warner illustrates what she has heard with musical notation, and her commentary can be ruthless as well as uproarious. Of one soprano in the Matthew Passion she writes in 1930:

As for the vibrato it grows worse and worse; very soon she will be indistinguishable from an electric drill, and they will be able to use her E flat to take up Piccadilly.

STW Archive

Her synaesthesia allows her to describe the impact of music in language: for example,

Dined at Sorrani's with Victor [Butler]...then on to the BBC to hear Oedipus Rex by and conducted by Stravinsky. A great deal of the choral writing was almost pure Taverner, the construction that of an early passion. It is really impressive music, it sounds old and cold, a chilly shadow that has never lifted from man's mind. $\quad$ STW Archive

Later when living far away from concert halls, radio performances became life-blood to her:

in the evening Handel's Choice of Hercules (a mistaken one) with Deller singing more beautifully than ever we have heard him. His 
phrasing is like the pattern on feathers, it is so flawless and so finished and so integral 15 June 1953, STW Archive

Listening to the third programme may have been how she first encountered Peter Pears and Benjamin Britten, before they became friends of hers. Peter Pears says that they met through his cousin Janet and her husband Reynolds Stone for whose engravings STW had composed accompanying verses (Warner 1980. p.7). In December 1951 she heard Billy Budd on the radio while on the $8^{\text {th }}$ she was at Covent Garden and 'had tea with Ben' and saw him again in the intervals at Covent Garden: 'the music becomes very familiar on a second hearing and winds itself into the mind.'

On $25^{\text {th }}$ June, 1953 she heard the third programme:

and in the evening I listened to the music of Aldeburgh - Pears singing 'Atu' dem Wasser...' exquisitely, and Britten's sharp, infallible composer's accompaniments ${ }^{2}$.

STW Archive

In the following year Britten and Pears gave a concert in Dorchester which she attended:

$10^{\text {th }}$ February, 1954

The Britten-Pears concert, with Britten's new cycle of Hardy poems. All have power, and his particular forthrightness, and poetic reading of the words: those I was most impressed by were The Travelling Boy, with its reiterated figure in the accompaniment, a bouncing futile phrase with the frustration of To Lincolnshire to Lancashire to buy a pocket handerkercher; and the last, Before Life and After; which is noble like a slow dance, sarabande-like solemn climbing. Pears was singing very well, his Nacht \& Traume superlative, and a Schubert I didn't 
know, Sprach der Liebe, most beautifully phrased. ... As for Britten, a head with no chin, a pounce like a weasel and a total attentiveness and identification with the music. Warner 1994, 206-207.

Later that year she heard a radio performance of The Tumn of the Screw and describes it in a letter in September 1954 to her friend the composer Paul Nordoff with a brilliance that takes us far into the uncanny interior of the music:

The scoring is very light, the tessitura inherently high, as well as his usual high tessitura, as the voices are two straight sopranos, a boy treble, and two dramatic sopranos: nothing lowcr, till the tenor comes in in scene 8 of the first act. This entry is marvellous. Quint has appeared before. mute, but conveyed by a twirligig passage for the celesta. In this scene 8 , when he is on the tower looking down at the two children, the celesta twirls are developed, there is no interruption of other singers, and then the tenor enters on a pedal note, very quietly, and the note so ambiguously in his middle register (perhaps $\mathrm{B}$ flat or $\mathrm{A}$ ) that it might be anything, the bottom note of a soprano or a viola. By the time the moderate crescendo has established that it is the tenor, the effect of something supernaturally dominating and yet furtive is overwhelming. It is exactly like what one is told of bad ghosts appearing: the growing sensation of intimidating cold. And the moment this is established, Quint begins a series of leaping, flickering coloratura phrases: the sort of coloratura one finds in Taverner's virtuoso masses.

Warner 1982, p. 150 
A lifetime of musical knowledge and life experience is caught together in that evocation.

By 1971 she knew both Pears and Britten well, though she always felt Britten's mystery. At the 1971 Aldeborough festival, when the John Craske exhibition was taking place, she had lunch at the Red House:

Sherry in the sun; then Ben: with hooded watchful eyes; an ear for conversation as if it were an orchestra. The mysterious outer life of the creative artist.

Warner 1994, pp.356-357

She recognised that "ear for conversation as if it were an orchestra' since she shared it in her own registering of the harmonics of conversation in the novels and short storjes.

Peter Pears she valued not only as an artist but for what she called 'his compassionate heart' (1994, p.364). Their musical friendship lasted to the end of her life. Pears quotes her final letter to him, dated $30^{\text {ll }}$ March 1978, a month before her death on May I ${ }^{\text {st }}$ 1978:

Dear Peter,

This may be my last letter. I want to send you my love and my thanks for all the beauty that your music has meant to me.

And keep an eye on the Craskes.

I've just been told that your singing of "Die Schöne Müllerin" with Murray Perahia accompanying, was beautiful. Deeply felt and a hymn to Ben. Sing on, my darling. My love, Sylvia

$$
\text { Warner 1980, p.9. }
$$

In the tribute to her at Aldeburgh the previous year, Pears read a number of her recent poems 'beautifully' she said, including 'Gloriana Dying' which images the dying queen intransigently lying on the floor and looking up, with the same mixture of pith, resistance, humour and insight that 
Warner herself displayed. These lines come from the centre of the poem.

\section{Gloriana Dying}

No, no! Leave me alone, woman! I will not

Be put into a bed. Do you suppose

That I who've ridden through all weathers, danced

Under a treasury's weight of jewels, sat

Myself to stone through sermons and addresses,

Shall come to harm by sleeping on a floor?

Not that I sleep. A bed were good enough

If that were in my mind. But I am here

For a decp study and contemplation,

And as Persephone, and the red vixen,

Go underground to sharpen their wits,

I have left my dais to learn a new policy

Through watching of your feet, and as the Indian

Lays all his listening body along the carth

I lie in wait for the reverberation

Of things to come and dangers threatening.

Warner 2008, p.366-367.

Sylvia Townsend Warner never lied to herself or her readers. She heard all the reverberations of 'things to come and dangers threatening'. She remained a political animal. She continued to be committed to unheeded or unheard voices, to those trapped by poverty and powerlessness. Yet her flair was not diminished by her commitment: pleasure lay at the core of her life. Mischief was a part of it. 'Happiness is the root of all, even of tragedy' she wrote to a friend in trouble. Music sustained the rhythms of her language, her understanding and her emotional life. For her, and through her, "the condition of being alive', as she called it, throngs with human voices, and with the stamina of human silences and the listening ear. 


\section{NOTES}

1. Available on YouTube - Benjamin Luxon Sings 'Songs Sacred and Profane' By John Ireland https://www.youtube.com/watch? $\mathrm{v}=\mathrm{x}$ I Xe9MgWaHQ

('The Scapegoat' is the last song and begins at about 12:14.)

2. Available on YouTube - Peter Pears and Benjamin Britten, Performances in Leningrad (live). 'Auf dem Wasser zu Singen' by Franz Schubert, Op.72, D.774. https://www.youtube.com/watch? $v=\mathrm{gl}$ lhyF _r.PVQ

\section{WORKS CITED}

BOND, J. JACOBS, M. (2008) "'Nefarious Activitics": Sylvia Townsend Warner, Valentine Ackland and M15 Surveillance 1935-1955', Jomnal of the Sylvia Townsend Waner Society pp.40-58.

HARMAN, C. (1989) Sylvia Townsend Warner: A Biography. London: Chatto \& Windus

SEARLE, R. (2011) 'Sylvia Townsend Warner and Tudor' Church Music', Journal of the Sy/via Townsend Warner Society pp.69-88.

WARNER, S.T. (1925) The Espalier. London: Chatto \& Windus.

(1927) Lolly Willowes. London: Chatto \& Windus. (1943) A Gartand of Straw. London: Chatto \& Windus. (1980) Twelve Poems. With Preface by Peter Pears. London: Chatto \& Windus.

(1982) Letters Ed. W. Maxwell. London: Chatto \& Windus.

(1988a) Selected Stories. London: Chatto \& Windus

(1988b) The Corner That Held Them. London: Virago Press.

(1989) After the Death of Don Juan. London: Virago Press 
(1994) The Diaries of Sylvia Tounsend Wanner: Ed. C. Harman. London: Chatto \& Windus. (2001 a) The Element of Lavishness. The Letters of Sylvia Tounsend Waner and William Maxiell 1938-1978. Ed. M. Stcinman. Washington D.C.: Counterpoint.

__ (2001b) The Music at Long Vernel: Tuenty Stories. Ed. M. Steinman. Washington D.C.: Counterpoint. (2008) New Collected Poems. Ed. C. Harman. Manchester: Carcanet Press.

(2011) 'Recommendation to Starvation'. Journal of the Sylva Tomnsend Wanner Socien pp.17-19. (2012) With the Hunted. Selected Writings of Sylvia Tonnsend Harner Ed. P. Tolhurst. Norwich: Black Dog Books. 
Copyrighted image removed

The Times $19^{\text {th }}$ September 1936 